\title{
Doğal Gaz ve Petrol Fiyatları ile BIST Sanayi Sektörü Endeksleri Arasındaki İlişkinin İncelenmesi ${ }^{1}$
}

\section{Examining the Relationship among the Natural Gas, Oil Prices and Sub- Indexes of BIST-Industrial}

\author{
Kemal Eyüboğlu, Karadeniz Teknik Üniversitesi, Türkiye, keyuboglu@ktu.edu.tr \\ Sinem Eyüboğlu, Karadeniz Teknik Üniversitesi, Türkiye, sinemyilmaz17@ hotmail.com
}

\begin{abstract}
Öz: Ülkelerin ekonomik olarak kalkınmasında sanayi sektörünün önemi büyüktür. Sanayi üretiminde kullanılan girdilerin başında ise enerji gelmektedir. Dolaylsiyla enerji fiyatlarında meydana gelecek bir dalgalanma sanayi sektörü şirketlerini etkileyebilecektir. Bu açıdan çalışmada, 2005:10-2015:09 dönemi için doğal gaz ve petrol fiyatları ile BIST Sanayi sektörü endeksleri arasinda uzun dönemli bir ilişskinin olup olmadiğı test edilmektedir. Bu çerçevede çalışmada Sinai, Taş-Toprak, Metal Ana, Kimya-Petrol-Plastik, Metal Eşya-Makina, Gida-İçecek, Tekstil-Deri ve OrmanKağıt-Basım endeksleri ile doğal gaz ve petrolün TL bazl fiyatları kullanılmıştır. Doğal gaz ve petrol fiyatları ile ilgili endeksler arasinda uzun dönemli ilişsi olup olmadığ ise, Johansen eşbütünleșme yöntemi ile test edilmiștir. Elde edilen bulgular hem doğal gaz hem de petrol fiyatları ile mevcut endeksler arasında uzun dönemli ilişki olduğunu göstermiş̧tir. Buna bağlı olarak VECM yardımı ile ilgili değişkenler arasında kısa dönem dinamikleri incelenmis ve petrol fiyatı ile Sinai, Taş-Toprak, Metal Ana, Kimya-Petrol-Plastik ve Orman-Kağıt-Basım endeksleri arasinda kisa dönemli ilişkinin mevcut olduğu belirlenmiştir. Granger nedensellik testi ile kısa dönemli elde edilen iliş̧kinin yönünün petrol fiyatından ilgili endekse doğru tek yönlü olarak gerçekleştiği desteklenmiştir.
\end{abstract}

Anahtar Sözcükler: Doğal Gaz Fiyatı, Petrol Fiyatı, Nedensellik, Borsa Istanbul

Abstract: The industry sector has major effect on the country's economic development. Energy is one of most used input in this sector. Hence a fluctuation in energy prices may affect the sector companies. The aim of the study to analyze, whether the long-term relationship between sub-indexes of BIST-Industrial, natural gas and oil prices during the period 2005:10-2015:09. For this purpose TL-based prices of natural gas, oil and sector indexes Nonmetal Mineral Products, Basic Metal, Chemical Petroleum Plastic, Metal Products Machinery, Food Beverage, Textile Leather and Wood Paper Printing are used. Whether long term relationship have tested with Johansen Cointegration. Results show that there has been a long-term relationship between the sector indexes and natural gas and brent oil prices. Short-term dynamics among the variables examined with VECM and it is found that there are short term relationship between oil and BIST-Industrial, Nonmetal Mineral Products, Basic Metal, Chemical Petroleum Plastic and Wood Paper Printing indexes. Also Granger Causality test supports the direction of relationships running one way from oil price to indexes.

Keywords: Natural Gas Price, Oil Price, Causality, Borsa Istanbul

\section{Giriş}

Günümüzde ikame edilemez olan enerji, ülkelerin ekonomik olarak gelişmeleri ve küresel açıdan rekabet edebilmeleri açısından en önemli unsurların başında gelmektedir. Enerji üretimi ise, büyük ölçüde fosil kaynaklara (petrol, kömür ve doğal gaz) dayanmaktadır. Yakın gelecekte de bu durumun devam edeceği ve birincil enerji ${ }^{2}$ arzındaki en büyük payların fosil kaynaklar olacağı öngörülmektedir. Dünyada birincil enerji kaynaklarının tüketim oranları incelendiğinde,

2013 yılı itibariyle \%33,1 oranla petrolün, \%30,3'lük pay ile kömürün ve ardından \%23,7 ile doğal gazın başı çektiği görülmektedir (TMMOB 2015: 1). Sanayi üretimindeki girdilerin başında da yine bu kaynaklar gelmektedir. Enerji tüketiminde dünyada sanayi sektörü en büyük paya sahiptir ve 2040 yılına kadar dünya enerji tüketiminin yarısından fazlasının yine sanayi sektörü tarafından gerçekleştirileceği öngörülmektedir (Yıldırım ve diğ. 2014: 94).

Doğal gaz, başta sanayi sektörü olmak üzere dünyada pek çok sektörde kullanılan önemli bir enerji kaynağıdır. 2030 yılına kadar doğal gazın, dünyada tüketimi en hızlı artış gösteren fosil yakıt olacağı tahmin edilmektedir (EPDK 2011: 15). Doğal gaz karbon yoğunluğunun kömüre ve petrole göre azlığı sebebiyle kullanım açısından önemli bir avantaj getirmektedir. Ayrıca enerji sektöründe, doğal gaz düşük maliyetli olması ve verimliliği nedeniyle de tercih edilmektedir. Amerikan Enerji Bilgi İdaresinin 2011 yılı raporuna göre, 2008 ve 2035 yılları arasında dünyanın doğal gaz tüketiminin 58 trilyon $\mathrm{m}^{3}$ artacağı öngörülmektedir (Güney Ege Kalkınma Ajansı 2012: 8).

Birincil enerji kaynaklarından bir diğeri olan petrol ise, ekonomi üzerinde önemli etkilere sahiptir. Bu etkinin en önemli nedeni petrolün pek çok sektörde girdi olarak kullanılmasıdır. Bu açıdan petrol, işletmeler için önemli bir maliyet unsuru teşkil ettiğinden dolayı petrol fiyatlarındaki değişimin işletmeler tarafından yakından takip edilmesi gerekmektedir (Abdioğlu ve Değirmenci 2014: 3).

\footnotetext{
1 Bu çalışmanın özeti 21-24 Ekim 2015 tarihleri arasında Hitit Üniversitesi tarafından düzenlenen 19. Finans Sempozyumu'nda bildiri olarak sunulmuştur.

${ }^{2}$ Herhangi bir dönüşümden geçmemiş haliyle enerji kaynakları, birincil enerji kaynakları olarak adlandırılmaktadır. Örneğin; kömür, petrol ve doğal gaz vb. (Demirtaş, 2013: 2).
} 
Türkiye'de enerji tüketimi yaşam standartlarının yükselmesi, nüfustaki artış, sanayi ve teknolojideki ilerlemelere paralel olarak hızla artmaktadır. Bu enerji tüketimindeki artışının Türkiye'de üretimi kısıtlı olan doğal gaz ve petrol gibi kaynaklara doğru yoğunlaşması ise, ülke ekonomisi üzerinde bir yük oluşturmakta ve ülkemizin önemli problemleri arasında yer almaktadır (TMMOB 2008: 1). Türkiye İstatistik Kurumu (TÜIK) verilerine göre, Türkiye'nin 2013 yılındaki toplam ithalatı 251 milyar 650 milyon 560 bin doları bulurken, bu miktarın 55 milyar 915 milyon 234 bin dolarlık bölümü “enerji ithalatı" olarak gerçekleşmiştir. Başka bir deyişle Türkiye, ithalat için ödediği her 100 doların 22,21 dolarını enerji ürünleri için harcamıştır (bloomberght.com). İlaveten Türkiye’nin toplam nihai enerji tüketimi TÜİK verilerine göre 2012 y1lında 89008 bin tep (bin ton petrol eşdeğeri) olarak hesaplanmıştır. Sanayi sektörü enerji tüketimi ise, 30382 bin tep ile nihai enerji tüketiminin \%34,1'ini oluşturmuştur. Bu açıdan enerji fiyatlarındaki dalgalanmalar özellikle önemli bir maliyet unsuru teşkil ettiği için sanayinin alt sektörleri üzerinde önemli etkiye sahiptir. Şirketlerin girdisi olan doğal gaz ve petrol fiyatının yükselmesi şirketlerin maliyetlerinin artmasına, bu durum da şirketlerin nakit akışlarının değişmesine neden olmaktadır. Bilindiği üzere bir şirketin değeri, gelecekte elde edeceği nakit akışlarının bugüne indirgenmiş değeri ile ölçülmektedir. Bu çerçevede şirketler açısından petrol veya doğal gaz fiyatlarında meydana gelecek bir artış şirketlerin gelecekteki nakit akışlarını negatif olarak etkileyecek ve şirketlerin değerini düşürebilecektir.

Türkiye, enerji ithal eden, enerji fiyatlarındaki artışlara paralel olarak yüksek oranda cari açık veren ve cari açığı dikkatle takip eden finansal piyasalara sahiptir. Bu açıdan, doğal gaz ve petrol fiyatlarının Türkiye'deki sanayi sektörü şirketlerini nasıl ve ne ölçüde etkilediğinin incelenmesinin şirketler, politika yapıcılar, yatırımcılar ve diğer paydaşlar açısından yol gösterici olacağı düşünülmektedir. Özellikle son zamanlarda söz konusu enerji fiyatlarında yaşanan değişimler, bu emtiaların hisse senetleri üzerindeki etkilerini ortaya koymak için de bir fursat yaratmıştır.

$\mathrm{Bu}$ çalışmanın amacı, uluslararası doğal gaz ve brent petrol fiyatlarının Borsa İstanbul'da işlem gören sanayi şirketlerinin oluşturduğu (Sınai, Taş-Toprak, Metal Ana, Kimya-Petrol-Plastik, Metal Eşya-Makina, Gıda-İंçecek, Tekstil-Deri ve Orman-Kağıt-Basım) endeksler üzerinde nasıl ve ne ölçüde etkili olduğunu incelemektir. Özellikle makroekonomik faktörlerin ve petrol fiyatlarının endeksler üzerindeki etkisi geçmişte bir çok çalışmada incelenmesine rağmen, üretim faaliyetlerinin önemli bir girdisi olan doğal gaz fiyatlarındaki dalgalanmaların etkisini inceleyen az sayıda çalışma bulunmaktadır. Bu açıdan çalışmanın literatüre önemli katkıları olacağı düşünülmektedir. Ayrıca geçmişte yapılan çalışmalarda genellikle endeks olarak genel endekslerin (BIST-100, S\&P 500 gibi) kullanıldı̆̆ı görülmektedir. Bu çalışmada ise, genel endeks kullanmak yerine sektör endekslerinden yararlanılmıştır.

Çalışma beş bölümden oluşmaktadır. Çalışmanın bundan sonraki bölümünde dünyada ve Türkiye'de doğal gaz ve petrol kullanımına ilişkin genel bilgilere, üçüncü bölümünde enerji fiyatlarının hisse senedi endeksleri üzerindeki etkilerini tespit etmeye yönelik çalışmalara yer verilmiştir. Dördüncü bölümde çalışmada kullanılan veri, yöntem hakkında bilgi verilmiş ve son bölümde ise, çalışmadan elde edilen bulgular özetlenerek yorumlanmıştır.

\section{Dünyada ve Türkiye’de Doğal Gaz ve Petrol Kullanımı}

Kömürden elde edilen doğal gaz, evleri ve sokakları aydınlatmada ilk olarak 1785 yılında Britanya'da daha sonra 1816 yılında Amerika'da kullanılmıştır. İlk yer altı doğal gaz kuyusu ise, 1859 yılında ABD’de açılmıştır (Beşergil 2007). Dünya ekonomilerindeki büyüme ve nüfus artışının yanı sıra enerji alanında yaşanan yapısal ve teknolojik gelişimlere de bağlı olarak birincil enerji arzının kompozisyonunda değişim yaşanmıştır. 1970’lerden itibaren petrol fiyatlarındaki artışında etkisiyle dünyada doğal gaz üretiminin ve kullanımının yaygınlaşması, doğal gaz ticareti için yeni boru hatlarının döşenmesi, elektrik üretimi için doğal gaz santrallerinin kullanılmaya başlanması ve nükleer santrallerin yaygınlaşması gibi gelişmeler enerji kaynaklarının dağılımında önemli değişikliklere neden olmuştur (Demirtaş 2013: 3). Doğal gaz toplumda temiz çevre bilincinin artmasıyla beraber revaçta bir enerji kaynağı olmuş, özellikle de 1973 petrol kriziyle beraber petrole bağımlı kalmak istemeyen devletler yeni enerji kaynaklarına yönelmişlerdir. Bu durum hem alternatif olması hem de çevre için temiz bir yakıt olması vesilesiyle doğal gazı popüler bir enerji kaynağı haline getirmiştir (Bilgin ve diğ. 2013: 58). 1973 yılında dünyada kaynaklar bazında birincil enerji tüketiminde \%14,8 paya sahip olan doğal gaz, yukarıda sayılan nedenlerin de etkisiyle Grafik 1'e göre 2013 yılı itibariyle payını yaklaşık \%23,7'ye çıkarmıştır (Sohtaoğlu ve Erbaş 2006: 17).

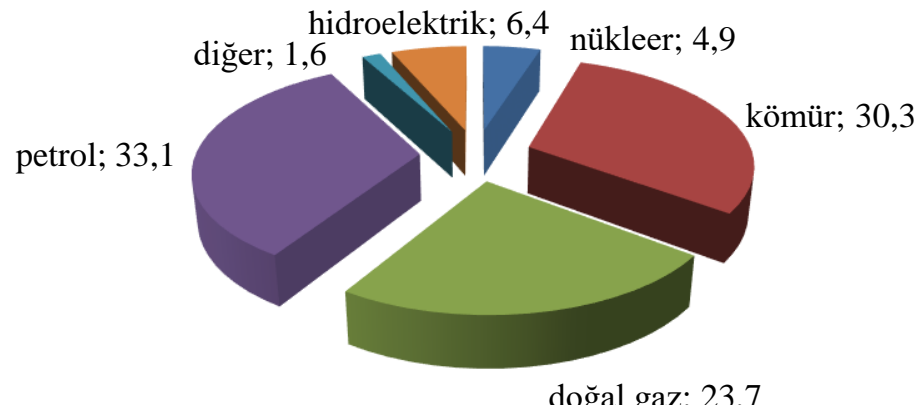

Grafik 1. 2013 İtibariyle Dünyada Kaynaklar Bazında Dünya Birincil Enerji Tüketimi (\%) 
Kaynak: TMMOB, 2015: 1

Dünyada kesinleşmiş doğal gaz rezervi 2012 yılı sonunda 187,3 trilyon $\mathrm{m}^{3}$ olarak belirlenmiş ve bu miktarın küresel üretimi 61 yıl boyunca karşılamaya yeteceği hesaplanmıştır. Rezervlerin dünyadaki dağılımları göz önüne alındığında ise, rezervlerin 76 trilyon $\mathrm{m}^{3}$ '̈̈ (\%41) Orta Doğu ülkelerinde, 59 trilyon $\mathrm{m}^{3}$ '̈̈ (\%33) Rusya ve Bağımsı Devletler Topluluğu ülkelerinde, 31 trilyon $\mathrm{m}^{3}$ 'ü (\%17) Afrika/Asya Pasifik ülkelerinde bulunmaktadır (GEKA 2012: 16; EPDK 2015: 6).

1970 yılında birincil enerji kaynağı olarak petrolün \%46’lık bir ağırlığa sahip olduğu görülmekteyken; bu oran 1990 y1lında \%37'ye, 2013'te ise \%33'e gerilemiştir. Ancak çeşitli uluslararası kurum ve kuruluşlar tarafindan (Uluslararası Enerji Ajansı, ABD Enerji Bakanlığı, BP, ExxonMobil vb.) yapılan tahminlere göre petrolün, birincil enerji tüketimi içindeki payını uzun dönemde de koruyacağı öngörülmektedir. Enerji kaynakları bazında talep artış oranlarının ise, 2012 y1lından 2035'e kadar olan dönemde; petrolde \% 13, kömürde \% 17, doğal gazda \% 48, nükleerde \% 66, yenilenebilir kaynaklarda ise \% 77 olacağı öngörülmektedir (Türkiye Petrolleri Anonim Ortaklığ1 2014: 4-5). Dünyada ise, toplam kanıtlanmış petrol rezervleri 1,7 trilyon varil civarında olup bu miktar, 54 yıllık tüketimi karşılamaktadır. Kalan üretilebilir petrol rezervlerinin yaklaşık \%60’1 kara, \%37’si deniz ve geri kalan kısmı Kuzey Kutbu'nda yer almaktadır. Geri kazanılabilir petrol kaynakları, çok kademeli hidrolik çatlatma gibi yeni teknolojilerin gelişmesi ve kaynak yerlerinin belirlenmesinde kullanılmaya başlanmasıyla birlikte artış göstermektedir (BP 2015: 6). Tablo 1'de ise, 2014 itibariyle dünyada doğal gaz ile petrol üretim ve tüketim miktarları gösterilmiştir.

Tablo 1. Dünyada Doğal Gaz ve Petrol Üretimi-Tüketimi (2014)

\begin{tabular}{|c|c|c|c|c|c|c|c|c|}
\hline \multirow[b]{2}{*}{ Bölgeler/Ülke } & \multicolumn{4}{|c|}{ Doğal gaz } & \multicolumn{4}{|c|}{ Petrol } \\
\hline & 兽 & 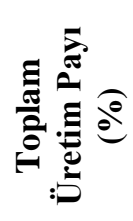 & 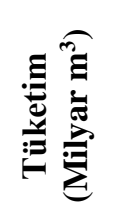 & 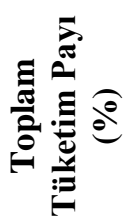 & 咅 & 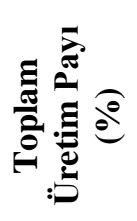 & 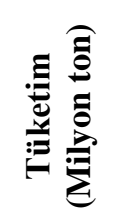 & 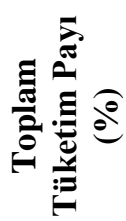 \\
\hline Kuzey Amerika & 948,4 & 27,7 & 949,4 & 28,3 & 866,8 & 20,5 & 1024,4 & 24,3 \\
\hline Orta ve Güney & 175 & 5 & 170,1 & 5 & 391 & 3,9 & 326,5 & 7,8 \\
\hline Avrupa- & 1002,4 & 28,8 & 1009,6 & 29,6 & 834,2 & 19,8 & 858,9 & 20,4 \\
\hline Ortadoğu & 601 & 17,3 & 465,2 & 6,3 & 1339,5 & 31,7 & 393 & 9,3 \\
\hline Afrika & 202,6 & 5,8 & 120,1 & 3,5 & 392,2 & 9,3 & 179,4 & 4,3 \\
\hline Asya Pasifik & 531,2 & 15,3 & 678,6 & 19,9 & 396,7 & 9,4 & 1428,9 & 33,9 \\
\hline $\mathrm{AB}$ & 132,3 & 3,8 & 386,9 & 11,4 & 67 & 1,6 & 592,5 & 14,1 \\
\hline Rusya & 578,7 & 16,7 & 409,2 & 12 & 534,1 & 12,7 & 148,1 & 3,5 \\
\hline $\mathrm{ABD}$ & 728,3 & 21,4 & 759,4 & 22,7 & 519,9 & 12,3 & 836,1 & 19,9 \\
\hline Türkiye & 0,5 & 0,01 & 48,6 & 1,4 & 17,1 & 0,4 & 33,8 & 0,8 \\
\hline Dünya & 3460,6 & 100 & 3393 & 100 & 4220,6 & 100 & 4211,1 & 100 \\
\hline
\end{tabular}

Kaynak: BP 2015: 10-27

Tablo 1'e göre 2014 yılında dünyadaki en büyük doğal gaz üretimi Rusya'nın etkisiyle Avrupa-Avrasya bölgesinde gerçekleştirilmiştir. Onu sırasıyla Kuzey Amerika ve Ortadoğu bölgeleri izlemektedir. En yüksek tüketim payına ise, sırasıyla Avrupa-Avrasya, Kuzey Amerika ve Asya Pasifik bölgeleri sahiptir. Ülkeler bazında dünyada en fazla üretim ve tüketim ABD tarafından gerçekleştirilmiştir. Türkiye ise, dünya doğal gaz üretiminde neredeyse hiçbir paya sahip değilken, tüketim açısından dünya tüketiminin \%1,4'lük payına sahiptir. Dünyadaki en büyük petrol üretimi Ortadoğu'da gerçekleştirilmiştir. Onu sırasıyla Kuzey Amerika ve Avrupa-Avrasya bölgeleri izlemektedir. En yüksek tüketim ise, sırasıyla Asya Pasifik, Avrupa-Avrasya ve Kuzey Amerika bölgelerinde gerçekleşmiştir. Ülkeler bazında Türkiye üretimde $\% 0,4$ 'lük, tüketimde $\% 0,8$ 'lik paya sahiptir.

Tablo 2'de Türkiye'de y1llar itibariyle doğal gaz üretim ve tüketim değerleri gösterilmiştir. Tablodan görüldüğü üzere Türkiye en yüksek doğal gaz üretim değerine 1014,5 milyon $\mathrm{m}^{3}$ ile 2008 yılında, 17,3 milyon varil ile de 2010 yılında en yüksek petrol üretim değerine ulaşmıştır. Doğal gaz tüketimi ise, yıllar itibariyle artmaktadır. 2004 yılında 22.505 milyon $\mathrm{m}^{3}$ olan doğal gaz tüketimi 2014 yılı itibariyle 2 katından fazla artarak 48.717 milyon m³'e yükselmiştir. Ancak aynı yıllar itibariyle petrol tüketimi giderek azalmaktadır. 
Tablo 2. Türkiye'de Yıllar İtibariyle Doğal Gaz ile Petrol Üretimi ve Tüketimi

\begin{tabular}{|c|c|c|c|c|}
\hline YIL & $\begin{array}{c}\text { DOGAL GAZ } \\
\text { ÜRETİMI } \\
(\text { milyon m³) }\end{array}$ & $\begin{array}{c}\text { PETROL } \\
\text { ÜRETIMMI } \\
\text { (milyon varil) }\end{array}$ & $\begin{array}{c}\text { DOĞGL GAZ } \\
\text { TÜKETİMİ } \\
(\text { milyon m³) }\end{array}$ & $\begin{array}{c}\text { PETROL } \\
\text { TÜKETIMI } \\
\text { (milyon ton) } \\
\end{array}$ \\
\hline 2004 & 707 & 15,9 & 22,505 & 30,6 \\
\hline 2005 & 896,4 & 15,9 & 27,467 & 29,3 \\
\hline 2006 & 906,6 & 15,1 & 31,128 & 29,9 \\
\hline 2007 & 893,1 & 14,8 & 34,600 & 27,7 \\
\hline 2008 & 1014,5 & 15,0 & 36,100 & 27,0 \\
\hline 2009 & 729,4 & 16,7 & 34,400 & 22,3 \\
\hline 2010 & 726 & 17,3 & 36,900 & 23,8 \\
\hline 2011 & 793,4 & 16,4 & 43,800 & 25,0 \\
\hline 2012 & 664,4 & 16,2 & 45,242 & 22,1 \\
\hline 2013 & 561,5 & 16,6 & 45,270 & 20,8 \\
\hline 2014 & 502,1 & 17,1 & 48,717 & 19,8 \\
\hline
\end{tabular}

Kaynak: EPDK 2015: 44-45

\section{Literatür Taraması}

Literatürde enerji fiyatları ile hisse senedi endeksleri arasındaki ilişkiyi tespit etmek üzere yapılmış çok sayıda çalışma bulunmaktadır. Ancak bu çalışmaların birçoğu petrol fiyatlarının hisse senedi fiyatları üzerindeki etkisini tespit etmeye yöneliktir. Doğal gaz fiyatlarının etkilerini inceleyen çalışmalar ise sınırlı sayıdadır. Ayrıca, bu çalışmaların çoğunda sektör endeksleri yerine BIST-100 ve S\&P 500 gibi genel endekslerden yararlanılmıştır. Çalışmalarda petrol ve doğal gaz fiyatlarının hisse senedi fiyatları üzerindeki etkilerine yönelik farklı bulgulara ulaşılmıştır. Enerji fiyatlarının hisse senetleri üzerinde etkisinin var olduğunu ortaya koyan çalışmalardan, Jones ve Kaul (1996), 1947-1991 döneminde 4 ülke için (ABD, Kanada, Japonya ve İngiltere) yapmış oldukları çalışmada, savaş sonrası dönemde ABD ve Kanada borsalarının petrol şoklarına tepkisinin reel nakit akışları ile açıklanabileceği ifade etmişlerdir. Sadorsky (1999) ise, 19471996 dönemi için petrol fiyatları ve petrol fiyatlarındaki oynaklıkların S\&P 500 endeksindeki hisse senedi getirilerini önemli ölçüde etkilediği sonucuna ulaşmıştır. Faff ve Brailsford (1999), 1983-1996 dönemi için Avustralya sanayi endeksi hisse senedi getirileri ile fiyatları arasındaki ilişkiyi test ettikleri çalışma sonucunda, petrol, doğal gaz ve çeşitlendirilmiş kaynak sanayileri ile petrol fiyatları arasında pozitif, kağıt, ambalaj ve ulaşım sanayi ile ise petrol fiyatları arasında negatif bir ilişki olduğunu vurgulamışlardır.

Papapetrou (2001) ise, Yunanistan'da 1989-1999 döneminde petrol fiyatları, hisse senetleri, faiz oranları ve reel ekonomik aktivite arasındaki ilişkiyi incelediği çalışmasında petrol fiyat şoklarının hisse senedi getirilerini negatif yönde etkilediğini ifade etmiştir. Boyer ve Filion (2004), 1995-2002 dönemi için Kanada'da petrol ve gaz şirketlerinin getirileri ile petrol ve doğal gaz fiyatları arasındaki ilişkiyi araştırmışlardır. Çalışma sonucunda doğal gaz fiyatları ve ham petrol fiyatları ile şirket getirileri arasında pozitif bir etki olduğunu ortaya koymuşlardır. Basher ve Sadorsky (2006) 1992-2005 dönemi için petrol fiyat değişikliklerinin gelişmekte olan 21 ülke borsası üzerindeki etkisini araştırdıkları çalışmalarında petrol fiyatlarının ülke borsaları üzerinde etkisi olduğu sonucuna ulaşmışlardır.

Nandha ve Hammoudeh (2007) 1994-2004 dönemi için Asya Pasifik Bölgesi’nde yer alan 15 ülkede petrol ile hisse senedi endeksi getirileri arasındaki ilişkiyi test etmişlerdir. Elde edilen bulgular, Filipinler ve Güney Kore'nin, yerel para cinsinden petrol fiyatındaki değişiklerine duyarlı olduğunu belirlemişlerdir. Amerikan doları cinsinden ise hiçbir ülkenin petrol fiyatlarına duyarlılık göstermediğini tespit etmişlerdir. Park ve Ratti (2008), 1986-2005 dönemi için petrol fiyatlarındaki şoklarının ABD ve 13 Avrupa ülkesinin hisse senedi endeks getirilerine olan etkisini incelemişlerdir. Sonuçlar Norveç'te hisse senedi getirileri ile petrol fiyatları arasında pozitif ilişki olduğunu göstermiştir. Malik ve Ewing (2009), ABD’de 1992-2008 dönemi için, Dow Jones’taki 5 sektör endeksi (Finans, Sanayi, Tüketim Hizmetleri, Sağlık ve Teknoloji) ile petrol fiyatları arasındaki ilişkiyi test etmişlerdir. Yapılan analizler sonucunda petrol fiyatları ile teknoloji, sağlık ve tüketim hizmetleri sektör getirileri arasında negatif ilişki olduğu tespit edilmiştir.

Narayan ve Narayan (2010), Vietnam'da 2000-2008 dönemi için petrol fiyatları ve döviz kurunun, hisse senetleri arasındaki ilişkiyi araştırmışlardır. Elde edilen bulgular, petrol fiyatları, hisse senedi fiyatları ve döviz kuru arasında uzun dönemli bir ilişki olduğunu göstermiştir. Ayrıca, petrol fiyatlarının hisse senedi fiyatlarına pozitif bir etkisinin olduğu belirlenmiştir. Le ve Chang (2011), 1986-2011 dönemi için Japonya, Singapur, Güney Kore ve Malezya'da hisse senedi piyasalarının petrol fiyatlarındaki oynaklıklara verdiği tepkiyi araştırdıkları çalışmalarında piyasanın Japonya'da pozitif, Malezya'da negatif, Singapur ve Güney Kore’de ise, verilen tepkinin belirsiz olduğunu tespit etmişlerdir. Masih ve diğ. (2011), Güney Kore'de 1988-2005 dönemi için hisse senedi piyasası, petrol fiyatları, sanayi üretimi ve faiz oranı arasındaki ilişkiyi incelemişlerdir. Yapılan analizler sonucunda petrol fiyatlarındaki dalgalanmaların hisse senedi piyasasını negatif olarak etkilediği ortaya koymuşlardır.

Adaramola (2012), Nijerya'da 1985-2009 dönemi için petrol fiyatları ile hisse senedi piyasası arasındaki ilişkiyi araştırdığ 1 çalışmasında hisse senetlerinin kısa dönemde petrol fiyatlarına pozitif, uzun dönemde ise negatif tepki 
verdiklerini ve petrol fiyatından hisse senetlerine doğru tek yönlü bir nedensellik olduğunu belirlemiştir. Li ve Wen (2012), Çin'de 1997-2012 dönemi için bazı makroekonomik değişkenler ile borsa sanayi endeksi arasındaki ilişkiyi analiz ettikleri çalışmaları sonucunda, sanayi endeksinin petrol fiyatları ile pozitif ilişkiye sahip olduğu sonucuna ulaşılmıştır. Asteriou ve diğ. (2013), 1988-2008 dönemi için petrol ihraç ve ithal eden ülke borsaları ile petrol fiyatları arasındaki ilişki incelemişlerdir. Elde edilen sonuçlar, petrol fiyatlarının ihraç eden ülkelerdeki etkisinin ithal eden ülke borsalarına göre daha fazla olduğunu göstermiştir.

Enerji fiyatlarının hisse senetleri üzerinde etkisinin olmadığını ortaya koyan çalışmalardan, Chen ve diğg. (1986), 1952-1983 dönemi için makroekonomik faktörler ve petrol fiyatlarının hisse senedi getirilerini sistematik bir şekilde etkileyip etkilemediğini araştırdıkları çalışmalarında petrol fiyatlarının hisse senedi piyasasına herhangi bir etkisi olmadığ1 sonucuna ulaşmışlardır. Huang ve diğ. (1996), 1983-1990 dönemi için ABD'de petrol future getirileri ile S\&P 500 arasındaki ilişkiyi incelediği çalışmalarında, petrol future getirilerinin S\&P 500 endeksi üzerinde büyük bir etkisi olmadığını belirlemişlerdir.

Türkiye için yapılan çalışmalarda Sarı ve Soytaş (2006), 1987-2004 dönemi için ham petrol fiyatında meydana gelen şokların, Türkiye'de hisse senetleri, büyüme ve enflasyon üzerindeki etkilerini inceledikleri çalışmalarında petrol fiyatlarındaki şokların hisse senedi getirileri üzerinde anlamlı bir etkiye sahip olmadığını ifade etmişlerdir.

Eryiğit (2009), 2000-2008 dönemi petrol fiyatlarında yaşanan değişimlerin Borsa İstanbul Endeksleri üzerindeki etkilerini incelemiştir. Çalışmadan elde edilen bulgular petrol fiyatlarının Elektrik, Toptan ve Perakende, Sigorta, Holding, Yatırım, Orman Kağıt Basım, Metal Ana, Metal Eşya Makine, Taş Toprak endeksleri üzerinde anlamlı etkisi olduğunu göstermiştir.

İşcan (2010), petrol fiyatları ile hisse senedi fiyatları arasındaki uzun dönemli ilişkiyi İMKB-100 endeksi için araştırdığı çalışmasında petrol fiyatları ile hisse senedi fiyatları arasında herhangi bir ilişki tespit edememiştir.

Güler ve diğ. (2010), 2000-2009 dönemi için petrol fiyatındaki değişimin Borsa İstanbul'da işlem gören enerji sektörü hisse senedi fiyatları üzerindeki etkisini test ettikleri çalışmalarında petrol fiyatının hisse senedi fiyatlarında önemli bir gösterge olduğunu belirlemişlerdir.

Toraman ve diğ. (2011), ham petrol fiyatlarının BIST-100, hizmetler, teknoloji ve sanayi endeksleri üzerindeki etkisini araştırdıkları çalışmaları sonucunda özellikle BIST-100 ve sanayi endekslerine yatırım yapacak yatırımcıların ham petrol fiyatlarındaki değişimleri dikkate almaları gerektiğini vurgulamışlardır.

Sayılgan ve Süslü (2011), 1996-2006 dönemi için gelişmekte olan ülkelerde (Arjantin, Brezilya, Endonezya, Macaristan, Malezya, Meksika, Polonya, Rusya, Şili, Türkiye ve Ürdün) makroekonomik değişkenlerin hisse senedi getirileri üzerindeki etkilerini incelemişlerdir. Elde edilen sonuçlar, petrol fiyatları ile hisse senedi getirileri arasında istatistiksel olarak anlamlı bir ilişki olmadığını göstermiştir.

Kapusuzoğlu (2011), 2000-2010 dönemi için BIST-100, BIST-50, BIST-30 endeksleri ile Brent petrol fiyatı arasındaki uzun ve kısa dönemli ilişkiyi incelemiştir. Elde edilen bulgular petrol fiyatları ile çalışmada kullanılan endeksler arasında uzun dönemli bir ilişki olduğunu, petrol fiyatından endekslere doğru tek yönlü bir nedensellik olduğunu göstermiştir.

Albayrak ve diğ. (2012), 2005-2012 dönemi için BIST-100 endeksi üzerinde yabancı portföy yatırımları, dolar kuru, altın fiyatı ve doğrudan yabancı yatırımların etkisi olup olmadığını test etmişlerdir. Çalışmadan elde edilen bulgular dolar kuru, altın fiyatları, ile yabancı portföy yatırımlarının BIST-100 endeksi üzerinde açık ve önemli bir etkisinin olduğunu göstermiştir.

Eryiğit (2012), 2005-2008 dönemi için BIST-100 endeksi üzerinde çeşitli makro değişkenlerin etkilerini incelediği çalışmasında petrol fiyat şoklarının, döviz kurunun ve faizin borsa üzerinde etkisi olduğu sonucuna ulaşmıştır.

Acaravcı ve diğ. (2012), 15 Avrupa Birliği ülkesinde 1990-2008 dönemi için doğal gaz fiyatları ve hisse senedi fiyatları arasındaki uzun dönemli ilişkiyi için test etmişlerdir. Elde edilen sonuçlar, Avusturya, Danimarka, Finlandiya, Almanya ve Lüksemburg için hisse senedi fiyatları ile doğal gaz fiyatları arasında uzun dönemli ilişki bulunduğunu ortaya koymuştur.

Ünlü ve Topçu (2012), 1990-2001 ve 2001-2011 dönemleri için petrol fiyatlarının Borsa İstanbul üzerindeki etkilerini test etmişlerdir. Çalışma sonucunda birinci dönemde BIST-100 endeksi ve ham petrol fiyatları arasında eşbütünleşme ve nedensellik ilişsisi olmadığını, ancak ikinci dönemde değişkenler arasında eşbütünleşme ilişkisi olduğu belirlenmiştir.

Acaravcı ve Reyhanoğlu (2013), 2001-2010 dönemi için enerji fiyatları ile İMKB-100 endeksi arasındaki uzun dönemli ilişkiyi inceledikleri çalışmalarında İMKB-100 endeksi, petrol fiyatları, doğal gaz fiyatları ve sanayi üretim endeksi değişkenleri arasında uzun dönemli ilişki olduğunu vurgulamışlardır. Ek olarak, doğal gaz fiyatlarından kaynaklanan bir şokun, İMKB-100 endeksi üzerinde pozitif yönlü bir etkisi olduğunu ifade etmişlerdir.

Güler ve Nalın (2013), 1997-2012 dönemi için ham petrol fiyatındaki değişimin İMKB-100, İMKB Sınai ve İMKB Kimya, Petrol-Plastik endeksleri arasındaki ilişki incelemişlerdir. Çalışma sonucunda ise, serilerin uzun dönemde birlikte hareket ettikleri, ancak kısa dönemde aralarında nedenselliğin olmadığı belirlenmiştir.

Öztürk ve diğ. (2013), 1997-2009 dönemi için petrol ve doğal gaz fiyatları ile İMKB imalat sektörü ve kimya-petrolplastik sektörü endeksleri arasındaki ilişkiyi inceledikleri çalışmaları sonucunda petrol fiyatları ile İMKB imalat sektörü ve kimya petrol- plastik sektörü endeksleri arasında bir eşbütünleşme ilişkisi olduğunu tespit etmişlerdir.

Özmerdivanlı (2014), 2003-2014 dönemi için petrol fiyatları ile BIST-100 endeksi arasındaki ilişkiyi incelediği çalışması sonucunda petrol fiyatları ile BIST-100 endeksi arasında uzun dönemli bir ilişki olduğunu belirlemiştir. İlaveten Granger nedensellik testi, BIST-100 endeksi kapanış fiyatlarından, petrol fiyatlarına doğru tek yönlü bir nedensellik ilişkisi olduğunu ortaya koymuştur. 
Abdioğlu ve Değirmenci (2014), 2005-2013 dönemi için petrol fiyatları ile hisse senedi fiyatları arasındaki ilişkiyi sektör bazında incelemişlerdir. Çalışma sonucunda ise sinai, kimya, tekstil ve iletişim sektörüne ilişkin hisse senedi fiyatları ve petrol fiyatları arasında uzun dönem ilişki olduğu tespit edilmiştir.

Yıldırım ve diğ . (2014), 1991-2013 dönemi için uluslararası ham petrol ve doğal gaz fiyatlarının Borsa İstanbul'da işlem gören sanayi şirketlerinin hisse senedi fiyatları üzerindeki etkisini test ettikleri çalışmaları sonucunda ham petrol ve doğal gaz fiyat endeksleri ile Borsa İstanbul sınai endeksi arasında uzun dönemli bir ilişki olduğunu belirlemişlerdir. İlaveten ham petrol fiyat endeksinden sinai endeksine doğru tek yönlü nedensellik, sınai endeksinden de doğal gaz fiyat endeksine doğru tek yönlü bir nedensellik ilişkisi olduğunu tespit etmişlerdir. Bununla birlikte regresyon analizi sonucunda ham petrol ve doğal gaz fiyatlarının hisse senedi fiyatlarını pozitif etkilediği ortaya koymuşlardır.

Gönüllü ve diğ. (2015), 2003-2012 dönemi için ham petrol fiyatındaki dalgalanmaların BIST-Petrol, Kimya ve Plastik Endeksi arasındaki ilişki inceledikleri çalışmalarında petrol fiyatlarının endeks üzerinde etkisi olduğu sonucuna ulaşmışlardır. Tablo 3 'te ise literatürde yer alan çalışmalar özetlenmiştir.

Tablo 3. Literatür Özeti

\begin{tabular}{|c|c|c|c|c|}
\hline Çalışma & Ülke & Emtia & Dönem & İlişki Durumu \\
\hline Chen ve diğ. (1986) & ABD & petrol & $1952-1983$ & Yok \\
\hline Jones ve Kaul (1996) & 4 ülke & petrol & 1947-1991 & Var \\
\hline Huang ve diğ. (1996) & $\mathrm{ABD}$ & petrol & $1983-1990$ & Yok \\
\hline Sadorsky (1999) & $\mathrm{ABD}$ & petrol & $1947-1996$ & Var \\
\hline Faff ve Brailsford (1999) & Avustralya & petrol ve doğal gaz & $1983-1996$ & Var \\
\hline Papapetrou (2001) & Yunanistan & petrol & 1989-1999 & Var \\
\hline Boyer ve Filion (2004) & Kanada & petrol ve doğal gaz & $1995-2002$ & Var \\
\hline Basher ve Sadorsky (2006) & 21 ülke & petrol & 1992- 2005 & Var \\
\hline Nandha ve Hammoudeh (2007) & 15 ülke & petrol & 1994-2004 & Var \\
\hline Park ve Ratti (2008) & 14 ülke & petrol & $1986-2005$ & Var (1 ülke) \\
\hline Malik ve Ewing (2009) & $\mathrm{ABD}$ & petrol & $1992-2008$ & Var \\
\hline Narayan ve Narayan (2010) & Vietnam & petrol & $2000-2008$ & Var \\
\hline Le ve Chang (2011) & 4 ülke & petrol & $1986-2011$ & Var (2 ülke) \\
\hline Masih ve diğ. (2011) & G. Kore & petrol & $1988-2005$ & Var \\
\hline Adaramola (2012) & Nijerya & petrol & $1985-2009$ & Var \\
\hline Li ve Wen (2012) & Çin & petrol & 1997-2012 & Var \\
\hline Asteriou ve diğ. (2013) & 30 ülke & petrol & $1988-2008$ & Var \\
\hline Sar1 ve Soytaş (2006) & Türkiye & petrol & $1987-2004$ & Yok \\
\hline Eryiğit (2009) & Türkiye & petrol & $2000-2008$ & Var \\
\hline İşcan (2010) & Türkiye & petrol & $2001-2009$ & Yok \\
\hline Güler ve diğ. (2010) & Türkiye & petrol & $2000-2009$ & Var \\
\hline Toraman ve diğ. (2011) & Türkiye & petrol & $2009-2011$ & Var \\
\hline Sayılgan ve Süslü (2011) & 11 ülke & petrol & $1996-2006$ & Yok \\
\hline Kapusuzoğlu (2011) & Türkiye & petrol & $2000-2010$ & Var \\
\hline Eryiğit (2012) & Türkiye & petrol & $2005-2008$ & Var \\
\hline Acaravc1 ve diğ. (2012) & 15 ülke & doğal gaz & $1990-2008$ & Var (5 ülke) \\
\hline Ünlü ve Topçu (2012) & Türkiye & petrol & $1990-2011$ & Var \\
\hline Acaravcı ve Reyhanoğlu (2013) & Türkiye & petrol ve doğal gaz & $2001-2010$ & Var \\
\hline Güler ve Nalın (2013) & Türkiye & petrol & $1997-2012$ & Var \\
\hline Öztürk ve diğ. (2013) & Türkiye & petrol ve doğal gaz & $1997-2009$ & Var \\
\hline Özmerdivanlı (2014) & Türkiye & petrol & $2003-2014$ & Var \\
\hline Abdioğlu ve Değirmenci (2014) & Türkiye & petrol & $2005-2013$ & Var \\
\hline Y1ldırım ve diğ. (2014) & Türkiye & petrol ve doğal gaz & $1991-2013$ & Var \\
\hline Gönüllü ve diğ. (2015) & Türkiye & petrol & $2003-2012$ & Var \\
\hline
\end{tabular}

\section{Veri Seti Ve Yöntem}

\subsection{Veri Seti}

2005:10-2015:09 dönemi için doğal gaz ve petrol (brent) fiyatlarının Borsa İstanbul'da hesaplanan 8 endeks üzerinde nasıl ve ne ölçüde etkili olduğunun belirlenmesinin amaçlandığ 1 bu çalışmada, değişkenlere ilişkin TL bazlı aylık fiyat verileri kullanılmıştır. Çalışmada ayrıca BIST-100 fiyat endeksi ile Sanayi Üretim Endeksi (SUE) kontrol değişkenleri olarak analizlere dahil edilmiştir. TL bazlı fiyatların belirlenmesinde aylık ortalama paritelerden yararlanılmıştır. Endekslere ilişkin veriler, Borsa İstanbul'un resmi sitesinden; SUE'ye ilişkin veriler TCMB internet sitesinden, doğal gaz ve petrol fiyatlarına ilişkin veriler ise, investing.com'dan elde edilmiştir. Tablo 4 'te çalışmada yer alan endekslere ilişkin bilgiler yer almaktadır. 
Eyüboğlu, K., Eyüboğlu, S. / Journal of Yasar University, 2016, 11/42, 150-162

Tablo 4. Çalı̧̧mada Yer Alan Endeksler

\begin{tabular}{|c|c|c|c|}
\hline Endeks Adı & Endeks Kodu & Endeks Başlangıç Tarihi & İşlem Gören Şirket Sayısı \\
\hline BIST SINAİ & XUSIN & 31.12 .1990 & 146 \\
\hline BIST TAŞ, TOPRAK & XTAST & 27.12 .1996 & 25 \\
\hline BIST METAL ANA & XMANA & 27.12 .1996 & 14 \\
\hline BIST KİMYA, PETROL, PLASTIK & XKMYA & 27.12 .1996 & 24 \\
\hline BIST METAL, EŞYA, MAKİNA & XMESY & 27.12 .1996 & 19 \\
\hline BIST GIDA, İCCEEK & XGIDA & 27.12 .1996 & 15 \\
\hline BIST TEKSTIL, DERI & XTEKS & 27.12 .1996 & 13 \\
\hline BIST ORMAN, KAĞIT, BASIM & XKAGT & 27.12 .1996 & \\
\hline
\end{tabular}

Kaynak: http://www.kap.gov.tr/sirketler/islem-goren-sirketler/endeksler.aspx, 18.01.2016

\subsection{Yöntem}

Çalışmada doğal gaz ve petrol fiyatı ile BIST sanayi endekslerine ilişkin fiyatlar arasında uzun dönemli ilişki olup olmadığı araştırılmıştır. Öncelikle kullanılan tüm değişkenlerin doğal logaritmaları alınmıştır. Ardından kullanılan serilerin durağan olduğu seviyeler tespit edilmiştir. Bu amaçla Genişletilmiş Dickey-Fuller (ADF) ve Phillips-Perron (PP) birim kök testlerinden yararlanılmıştır. Bu testlerden ADF yaklaşımında istatistiksel olarak hata terimlerinin bağımsız ve homojen oldukları varsayılırken, PP yaklaşımında hata terimlerinin bağımlı ve heterojen oldukları varsayılmaktadır (Dickey ve Fuller 1979; 1981; Phillips ve Perron 1988).

ADF testi için (1) ve (2) numaralı denklemler kullanılmıştır. (1) numaralı denklem sabitli, (2) numaralı denklem ise, sabitli ve trendli ADF denklemlerini göstermektedir. ADF denklemlerinde olası otokorelasyon probleminin önlenmesi amacıyla bağımlı değişkenin gecikmeleri denklemin sağ tarafına açıklayıcı değişken olarak eklenmektedir. ADF denklemlerinde bağımlı değişkenin gecikme uzunluklarının belirlenmesi için Schwarz Bilgi Kriteri (SIC) kullanılmıştır.

$$
\begin{aligned}
& \Delta y_{t}=\beta+\delta y_{t-1}+\sum_{i=1}^{p} \phi_{i} \Delta y_{t-i}+\varepsilon_{t} \\
& \Delta y_{t}=\beta+\delta y_{t-1}+\sum_{i=1}^{p} \phi_{i} \Delta y_{t-i}+\text { ytrend }+\varepsilon_{t} \\
& \Delta y_{t}=\delta y_{t-1}+\sum_{i=1}^{p} \phi_{i} \Delta y_{t-i}+\varepsilon_{t}
\end{aligned}
$$

(1), (2) ve (3) numaralı denklemlerde y; durağanlığı incelenen değişkeni $\beta, \delta, \varphi$ ve $\gamma$; katsayıları, $\varepsilon$; hata terimini ve $\mathrm{p}$ ise en uygun gecikme uzunluğunu göstermektedir. $\delta$ katsayısının $\mathrm{t}$ istatistiği MacKinnon tablo kritik değeriyle karşılaştırılarak serinin durağan olup olmadığına karar verilir. Ĕger t istatistiğinin mutlak değeri MacKinnon tablo kritik değerinin mutlak değerinden büyükse seri seviyesinde durağandır.

PP testinde bağımlı değişken gecikmeleri söz konusu değildir. Çünkü PP testinde Newey-West bağımlı değişken gecikmelerini tespit eden bir uyarlama tahmincisidir. PP testi için (4) ve (5) numaralı denklemlerden yararlanılmıştır.

$\Delta \mathrm{y}_{\mathrm{t}}=\beta+\delta \mathrm{y}_{\mathrm{t}-1}+\mu_{\mathrm{t}}$

$\Delta \mathrm{y}_{\mathrm{t}}=\beta+\delta \mathrm{y}_{\mathrm{t}-1}+\gamma$ trend $+\mu_{\mathrm{t}}$

(4) ve (5) numaralı denklemlerde y; durağanlığı incelenen değişkeni $\beta, \delta$ ve $\gamma$; katsayıları, $\mu$ ise hata terimini ifade etmektedir. $\delta$ katsayısının $t$ istatistiği MacKinnon tablo kritik değeriyle karşılaştırılarak serinin durağan olup olmadığına karar verilir.

Çalışmada seriler arasındaki olası uzun dönem ilişkinin tespit edilmesi amacıyla Johansen (1988) ile Johansen ve Juselius (1990) eş bütünleşme yöntemi kullanılmıştır. Johansen eş bütünleşme yöntemi aynı seviyede durağan olan seriler arasındaki uzun dönem ilişkiyi test etmek amacıyla kullanılmaktadır. Bu yöntem durağan olmayan zaman serileri arasındaki eş bütünleşme vektörlerini göstermek için maksimum olabilirlik sürecine başvurmaktadır. Bu süreç durağan olmayan serilerin vektör otoregresif (VAR) model ile tahmin edilmesi sonucu elde edilir. $\Delta \mathrm{X}_{\mathrm{t}}=\sum_{\mathrm{i}=1}^{\mathrm{k}-1} \Gamma_{\mathrm{i}} \Delta \mathrm{X}_{\mathrm{t}-\mathrm{i}}+\pi \mathrm{X}_{\mathrm{t}-\mathrm{k}}+\delta+\eta_{\mathrm{t}}$

(6) numaralı denklemde X; durağan olmayan değişkenler vektörünü ve $\delta$ ise sabit terimi ifade etmektedir. $\pi=\alpha \beta^{\prime}$ 'dır. $\alpha$ matrisi uyarlama katsayısını, $\beta$ matrisi ise eş bütünleşme vektörlerini göstermektedir. Johansen (1988) prosedürü bir matrisin rankı ile onun karakteristik kökleri arasındaki ilişkiye dayanmaktadır. Teste göre karakteristik köklerin sayısı (7) numaralı iz (trace) ve (8) numaralı maksimum öz değer (max) istatistikleri ile belirlenebilir.

$$
\begin{aligned}
& \lambda_{\text {trace }}(\mathrm{r})=-\mathrm{T} \sum_{\mathrm{i}=\mathrm{r}+1}^{\mathrm{n}} \ln \left(1-\hat{\lambda}_{\mathrm{i}}\right) \\
& \lambda_{\text {max }}(\mathrm{r}, \mathrm{r}+1)=-\mathrm{T} \ln \left(1-\hat{\lambda}_{\mathrm{r}+1}\right)
\end{aligned}
$$


(7) ve (8) numaralı eşitliklerde $\lambda_{i}$; karakteristik birim köklerin tahmini değerini, $\mathrm{T}$; gözlem sayısını ve $\mathrm{r}$ ise eş bütünleşme vektörlerinin sayısını ifade etmektedir. Johansen eş bütünleşme testine göre hesaplanan iz ve maksimum öz değer istatistikleri Johansen ve Juselius (1990) tarafından sunulan kritik değerler ile karşılaştırılmak suretiyle eş bütünleşme ilişkisi olup olmadığı tespit edilir. Hesaplanan iz ve maksimum öz değer istatistikleri kritik değerlerden büyük ise seriler arasında uzun dönemli ilişkinin var olduğuna karar verilir.

Çalışmada uzun dönem ilişki tespit edilen seriler arasında, hem uzun dönemli denge ilişkileri hem de mevcut dengesizliğin ne kadarının kısa dönemde giderilip giderilemediği Vektör Hata Düzeltme Modeli (VECM) ile ortaya konulmuştur. Buna yönelik olarak aşağıda gösterilen 9 numaralı model tahmin edilmiştir.

$\Delta X_{t}=\alpha+\sum_{i=1}^{m} \beta_{i} \Delta X_{t-i}+\sum_{i=1}^{n} \delta_{i} \Delta Y_{t-i}+\sum_{i=1}^{p} \theta_{i} \Delta Z_{t-i}+\sum_{i=1}^{r} \phi_{i} \Delta S_{t-i}+\lambda E C_{t-1}+e_{t}$

9 numaralı denklemde $\lambda$, hata düzeltme parametresini ifade etmektedir. İlgili değiş̧kenin uzun dönem denge değerine yaklaşabilmesi için $\lambda$ 'nın negatif ve anlamlı olması gerekir. $\beta_{i}, \delta_{i}, \theta_{i}, \phi_{i}$ katsayıları ise kısa dönem parametreleridir. Bu parametrelerin bir bütün halinde anlamlllığını gösteren $\mathrm{F}$ değerinin veya hata düzeltme teriminin anlamlılığını gösteren $t$ değerinin anlamlı olması nedenselliğin mevcut olduğuna işaret etmektedir. Nedensellik olduğu tespit edilen değişkenler arasında nedenselliğin yönü VAR sistemine dayalı Granger (1969) nedensellik testi ile belirlenmiştir.

\section{BULGULAR}

Değişkenlerin tanımlayıcı istatistiklerinin yer aldığı Tablo 5'e göre, en yüksek oynaklığa sahip olan seriler LXMESY ve LXGIDA endeksleri iken, en düşük oynaklığa sahip olan seriler LSUE ve LXTAST endeksleridir.

Tablo 5. Tanımlayıcı İstatistikler

\begin{tabular}{|c|c|c|c|c|c|c|c|c|c|c|c|c|}
\hline & 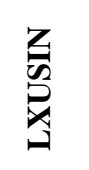 & 勾 & 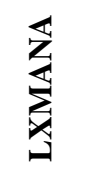 & 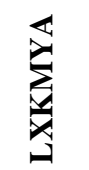 & 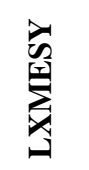 & $\underset{\nearrow}{\overleftrightarrow{્}}$ & $\frac{2}{x}$ & 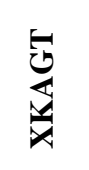 & 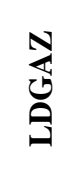 & 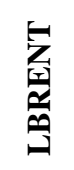 & 蓣 & $\begin{array}{l}8 \\
\frac{1}{1} \\
\frac{6}{a} \\
\frac{0}{a}\end{array}$ \\
\hline Ortalama & 10.72 & 10.92 & 10.94 & 10.40 & 10.71 & 11.17 & 9.13 & 10.36 & 2.06 & 4.93 & 0.01 & 10.90 \\
\hline Maksimum & 11.32 & 11.38 & 11.79 & 11.10 & 11.58 & 11.83 & 9.77 & 10.82 & 2.83 & 5.48 & 0.19 & 11.40 \\
\hline Minimun & 9.85 & 10.11 & 10.12 & 9.55 & 9.33 & 10.36 & 8.06 & 9.52 & 1.33 & 4.25 & -0.28 & 10.09 \\
\hline St. Sapma & 0.38 & 0.26 & 0.42 & 0.37 & 0.52 & 0.48 & 0.47 & 0.27 & 0.29 & 0.35 & 0.08 & 0.32 \\
\hline Carpıklık & -0.27 & -1.26 & 0.01 & -0.25 & -0.44 & -0.07 & -0.50 & -1.05 & 0.27 & -0.11 & -0.21 & -0.52 \\
\hline Basıklık & 2.21 & 4.75 & 2.50 & 2.37 & 3.15 & 1.47 & 2.00 & 3.96 & 3.27 & 1.66 & 3.35 & 2.51 \\
\hline Gözlem & 120 & 120 & 120 & 120 & 120 & 120 & 120 & 120 & 120 & 120 & 120 & 120 \\
\hline
\end{tabular}

ADF ve PP birim kök testleri ile öncelikle serilerin durağan oldukları seviyeler belirlenmiştir. Tablo 6, değişkenlere ait birim kök testi sonuçlarını göstermektedir. Tablo 6'da görüldüğü üzere değişkenlerin 1. farkında durağan olduğu belirlenmiştir.

Tablo 6. Değişkenlere Ait Birim Kök Sonuçları

\begin{tabular}{|c|c|c|c|c|c|c|c|c|}
\hline \multirow{3}{*}{ Değişkenler } & \multicolumn{4}{|c|}{ I $(\mathbf{0})$} & \multicolumn{3}{c|}{ I (1) } \\
\cline { 2 - 9 } & Sabitli & $\begin{array}{c}\text { Sabitli ve } \\
\text { Trendli }\end{array}$ & Sabitli & $\begin{array}{c}\text { Sabitli ve } \\
\text { Trendli }\end{array}$ & Sabitli & $\begin{array}{c}\text { Sabitli ve } \\
\text { Trendli }\end{array}$ & Sabitli & $\begin{array}{c}\text { Sabitli ve } \\
\text { Trendli }\end{array}$ \\
\hline LXUSIN & -1.130 & -2.008 & -1.315 & -2.455 & $-9.433^{\mathrm{a}}$ & $-9.391^{\mathrm{a}}$ & $-9.447^{\mathrm{a}}$ & $-9.405^{\mathrm{a}}$ \\
\hline LXTAST & -1.813 & -2.264 & -2.150 & -2.303 & $-9.013^{\mathrm{a}}$ & $-8.966^{\mathrm{a}}$ & $-8.972^{\mathrm{a}}$ & $-8.924^{\mathrm{a}}$ \\
\hline LXMANA & -1.667 & -2.482 & -1.829 & -2.949 & $-9.396^{\mathrm{a}}$ & $-9.357^{\mathrm{a}}$ & $-9.423^{\mathrm{a}}$ & $-9.385^{\mathrm{a}}$ \\
\hline LXKMYA & -0.817 & -2.139 & -1.021 & -2.531 & $-9.941^{\mathrm{a}}$ & $-9.919^{\mathrm{a}}$ & $-9.958^{\mathrm{a}}$ & $-9.933^{\mathrm{a}}$ \\
\hline LXMESY & -0.877 & -2.187 & -1.028 & -2.119 & $8.264^{\mathrm{a}}$ & $-8.261^{\mathrm{a}}$ & $-8.364^{\mathrm{a}}$ & $-8.348^{\mathrm{a}}$ \\
\hline LXGIDA & -1.012 & -2.314 & -1.339 & -2.059 & $-12.930^{\mathrm{a}}$ & $-12.911^{\mathrm{a}}$ & $-12.898^{\mathrm{a}}$ & $-12.877^{\mathrm{a}}$ \\
\hline LXTEKS & -1.163 & -1.491 & -1.315 & -1.851 & $-9.293^{\mathrm{a}}$ & $-9.244^{\mathrm{a}}$ & $-9.303^{\mathrm{a}}$ & $-9.255^{\mathrm{a}}$ \\
\hline LXKAGT & -1.992 & -2.121 & -2.147 & -2.306 & $-11.754^{\mathrm{a}}$ & $-11.700^{\mathrm{a}}$ & $-9.303^{\mathrm{a}}$ & $-9.255^{\mathrm{a}}$ \\
\hline LDGAZ & -2.564 & -3.008 & -2.267 & -2.196 & $-10.949^{\mathrm{a}}$ & $-10.980^{\mathrm{a}}$ & $-11.704^{\mathrm{a}}$ & $-11.653^{\mathrm{a}}$ \\
\hline LBRENT & -2.127 & -2.298 & 1.964 & -2.231 & $-8.572^{\mathrm{a}}$ & $-8.621^{\mathrm{a}}$ & $-8.647^{\mathrm{a}}$ & $-8.685^{\mathrm{a}}$ \\
\hline LSUE & -2.131 & -2.115 & $-50.571^{\mathrm{a}}$ & $-50.278^{\mathrm{a}}$ & $-9.567^{\mathrm{a}}$ & $-9.504^{\mathrm{a}}$ & $-89.217^{\mathrm{a}}$ & $-88.739^{\mathrm{a}}$ \\
\hline LBIST-100 & -1.665 & -2.589 & -1.768 & -2.558 & $-8.318^{\mathrm{a}}$ & $-8.287^{\mathrm{a}}$ & $-8.256^{\mathrm{a}}$ & $-8.227^{\mathrm{a}}$ \\
\hline
\end{tabular}

a $\% 1$ anlamlılık düzeyini göstermektedir.

Aynı seviyede durağan olduğu belirlenen doğal gaz fiyatları ile ilgili endeksler ve brent petrol fiyatları ile ilgili endeksler arasındaki uzun dönem iliş̧inin var olup olmadığ Johansen eşbütünleşme testi ile araştırılmıştır. Johansen 
eşbütünleşme testi için ise ilk önce Vektör Otoregressif (VAR) modelin gecikme uzunluğunun belirlenmesi gerekmektedir.

Johansen eşbütünleşme testi yapılırken ortaya çıkan en büyük sorun en uygun model formunun belirlenmesidir. Çalışmada en uygun model ise Pantula ilkesine göre belirlenmiştir. Pantula ilkesine göre her bir şirket için en uygun model 2 olarak belirlenmiştir. Bu nedenle Model 2 "sabit terimli eşbütünleşme denklemi ve sabit terimsiz VAR model sonuçları” dikkate alınmıştır. Test sonuçları ise Tablo 7'de gösterilmiştir. Buna göre doğal gazve kontrol değişkenleri ile XUSIN, XTAST, XKMYA, XMESY ve XGIDA, petrol ile XUSIN, XTAST, XMANA, XKMYA, XMESY, XTEKS ve XKAGT endeks serileri arasında bir eşbütünleşik vektör olduğu sonucuna ulaşılmaktadır. İlaveten doğal gaz ile XMANA, XTEKS ve XKAGT, petrol ve kontrol değişkenleri ile XGIDA endeksleri arasında iki eşbütünleşik vektör olduğu belirlenmiştir.Tablodaki sonuçlar incelendiğinde hem iz istatistiği hem de en yüksek öz değer istatistiği açısından ele alınan seriler arasında uzun dönemli bir ilişkinin varlığı görülmektedir. Yani çalışmada mevcut bulunan değişkenlerin ilgili vektörleri arasında uzun dönem ilişki mevcuttur.

Tablo 7. Johansen Eşbütünleşme Testi Sonuçları

\begin{tabular}{|c|c|c|c|c|c|}
\hline $\mathbf{H}_{\mathbf{0}}$ & Özdeğer & İz İstatistiği & Olasılık & $\begin{array}{c}\text { En Yüksek } \\
\text { Özdeğer İstatistiği }\end{array}$ & Olasılık \\
\hline \multicolumn{6}{|c|}{ LXUSIN LDGAZ LSUE LBIST-100 } \\
\hline $\mathrm{r}=0$ & 0.334266 & $66.48900^{\mathrm{a}}$ & 0.0004 & $45.16195^{\mathrm{a}}$ & 0.0001 \\
\hline$r \leq 1$ & 0.128082 & 21.32705 & 0.3376 & 15.21368 & 0.2742 \\
\hline$r<2$ & 0.052338 & 6.113370 & 0.6821 & 5.967041 & 0.6174 \\
\hline$r \leq 3$ & 0.001317 & 0.146329 & 0.7021 & 0.146329 & 0.7021 \\
\hline \multicolumn{6}{|c|}{ LXTAST LDGAZ LSUE LBIST-100 } \\
\hline $\mathrm{r}=0$ & 0.495821 & $101.5236^{\mathrm{a}}$ & 0.0000 & $79.43948^{\mathrm{a}}$ & 0.0000 \\
\hline $\mathrm{r}<1$ & 0.109263 & 22.08415 & 0.2939 & 13.42186 & 0.4142 \\
\hline$r<2$ & 0.040070 & 8.662298 & 0.3975 & 4.743859 & 0.7738 \\
\hline$r \leq 3$ & 0.033215 & 3.918439 & 0.0478 & 3.918439 & 0.0478 \\
\hline \multicolumn{6}{|c|}{ LXMANA LDGAZ LSUE LBIST-100 } \\
\hline $\mathrm{r}=0$ & 0.474775 & $111.1526^{\mathrm{a}}$ & 0.0000 & $74.69570^{\mathrm{a}}$ & 0.0000 \\
\hline $\mathrm{r}<1$ & 0.189910 & $36.45687^{\mathrm{a}}$ & 0.0074 & $24.43076^{\mathrm{b}}$ & 0.0165 \\
\hline $\mathrm{r}<2$ & 0.069445 & 12.02612 & 0.1557 & 8.349028 & 0.3443 \\
\hline$r<3$ & 0.031202 & 3.677088 & 0.0552 & 3.677088 & 0.0552 \\
\hline \multicolumn{6}{|c|}{ LXKMYA LDGAZ LSUE LBIST-100 } \\
\hline$r=0$ & 0.462164 & $99.90125^{\mathrm{a}}$ & 0.0000 & $71.94349^{\mathrm{a}}$ & 0.0000 \\
\hline$r \leq 1$ & 0.150172 & 27.95777 & 0.0803 & 18.87568 & 0.1005 \\
\hline$r<2$ & 0.067624 & 9.082085 & 0.3578 & 8.122197 & 0.3664 \\
\hline$r \leq 3$ & 0.008241 & 0.959888 & 0.3272 & 0.959888 & 0.3272 \\
\hline \multicolumn{6}{|c|}{ LXMESY LDGAZ LSUE LBIST-100 } \\
\hline $\mathrm{r}=0$ & 0.256187 & $61.80185^{\mathrm{a}}$ & 0.0015 & $32.85212^{\mathrm{a}}$ & 0.0096 \\
\hline $\mathrm{r}<1$ & 0.150455 & 28.94973 & 0.0624 & 18.09909 & 0.1262 \\
\hline$r<2$ & 0.091849 & 10.85064 & 0.2208 & 10.69429 & 0.1702 \\
\hline$r<3$ & 0.001408 & 0.156347 & 0.6925 & 0.156347 & 0.6925 \\
\hline \multicolumn{6}{|c|}{ LXGIDA LDGAZ LSUE LBIST-100 } \\
\hline $\mathrm{r}=0$ & 0.460962 & $97.96982^{\mathrm{a}}$ & 0.0000 & $71.68447^{\mathrm{a}}$ & 0.0000 \\
\hline$r \leq 1$ & 0.132988 & 26.28535 & 0.1204 & 16.55352 & 0.1941 \\
\hline$r<2$ & 0.071133 & 9.731823 & 0.3019 & 8.559605 & 0.3246 \\
\hline$r \leq 3$ & 0.010054 & 1.172218 & 0.2789 & 1.172218 & 0.2789 \\
\hline \multicolumn{6}{|c|}{ LXTEKS LDGAZ LSUE LBIST-100 } \\
\hline $\mathrm{r}=0$ & 0.490467 & $110.0857^{\mathrm{a}}$ & 0.0000 & $78.21419^{\mathrm{a}}$ & 0.0000 \\
\hline $\mathrm{r}<1$ & 0.176960 & $31.87153^{\mathrm{b}}$ & 0.0284 & $22.59103^{\mathrm{b}}$ & 0.0310 \\
\hline $\mathrm{r}<2$ & 0.062997 & 9.280498 & 0.3401 & 7.547983 & 0.4265 \\
\hline$r<3$ & 0.014824 & 1.732515 & 0.1881 & 1.732515 & 0.1881 \\
\hline \multicolumn{6}{|c|}{ LXKAGT LDGAZ LSUE LBIST-100 } \\
\hline $\mathrm{r}=0$ & 0.459815 & $102.8263^{\mathrm{a}}$ & 0.0000 & $71.43779^{\mathrm{a}}$ & 0.0000 \\
\hline $\mathrm{r} \leq 1$ & 0.164135 & $31.38846^{\mathrm{b}}$ & 0.0325 & 20.79742 & 0.0556 \\
\hline$r<2$ & 0.070444 & 10.59104 & 0.2380 & 8.473574 & 0.3326 \\
\hline $\mathrm{r} \leq 3$ & 0.018088 & 2.117464 & 0.1456 & 2.117464 & 0.1456 \\
\hline \multicolumn{6}{|c|}{ LXUSIN LBRENT LSUE LBIST-100 } \\
\hline$r=0$ & 0.399641 & $82.99194^{\mathrm{a}}$ & 0.0000 & $57.65578^{\mathrm{a}}$ & 0.0000 \\
\hline $\mathrm{r} \leq 1$ & 0.165358 & 25.33616 & 0.1498 & 20.42501 & 0.0625 \\
\hline $\mathrm{r}<2$ & 0.034637 & 4.911144 & 0.8182 & 3.983399 & 0.8611 \\
\hline$r<3$ & 0.008177 & 0.927745 & 0.3354 & 0.927745 & 0.3354 \\
\hline \multicolumn{6}{|c|}{ LXTAST LBRENT LSUE LBIST-100 } \\
\hline $\mathrm{r}=0$ & 0.416372 & $80.35655^{\mathrm{a}}$ & 0.0000 & $60.84963^{\mathrm{a}}$ & 0.0000 \\
\hline $\mathrm{r}<1$ & 0.090365 & 19.50693 & 0.4569 & 10.70240 & 0.6769 \\
\hline $\mathrm{r}<2$ & 0.052207 & 8.804525 & 0.3838 & 6.058921 & 0.6057 \\
\hline $\mathrm{r}<3$ & 0.024005 & 2.745605 & 0.0975 & 2.745605 & 0.0975 \\
\hline \multicolumn{6}{|c|}{ LXMANA LBRENT LSUE LBIST-100 } \\
\hline$r=0$ & 0.475305 & $93.92749^{\mathrm{a}}$ & 0.0000 & $74.81275^{\mathrm{a}}$ & 0.0000 \\
\hline $\mathrm{r} \leq 1$ & 0.110615 & 19.11474 & 0.4847 & 13.59807 & 0.3989 \\
\hline $\mathrm{r}<2$ & 0.027587 & 5.516667 & 0.7518 & 3.245007 & 0.9291 \\
\hline $\mathrm{r} \leq 3$ & 0.019393 & 2.271660 & 0.1318 & 2.271660 & 0.1318 \\
\hline \multicolumn{6}{|c|}{ LXKMYA LBRENT LSUE LBIST-100 } \\
\hline $\mathrm{r}=0$ & 0.404467 & $83.47128^{a}$ & 0.0000 & $58.56779^{\mathrm{a}}$ & 0.0000 \\
\hline $\mathrm{r}<1$ & 0.164950 & 24.90349 & 0.1649 & 20.36983 & 0.0636 \\
\hline $\mathrm{r}<2$ & 0.036549 & 4.533661 & 0.8561 & 4.207360 & 0.8368 \\
\hline $\mathrm{r} \leq 3$ & 0.002883 & 0.326301 & 0.5678 & 0.326301 & 0.5678 \\
\hline \multicolumn{6}{|c|}{ LXMESY LBRENT LSUE LBIST-100 } \\
\hline $\mathrm{r}=0$ & 0.442612 & $90.62202^{\mathrm{a}}$ & 0.0000 & $66.04781^{\mathrm{a}}$ & 0.0000 \\
\hline $\mathrm{r}<1$ & 0.137458 & 24.57421 & 0.1772 & 16.70952 & 0.1862 \\
\hline
\end{tabular}




\begin{tabular}{|c|c|c|c|c|c|}
\hline $\mathrm{r}<2$ & 0.059445 & 7.864696 & 0.4800 & 6.925242 & 0.4980 \\
\hline $\mathrm{r}<3$ & 0.008279 & 0.939454 & 0.3324 & 0.939454 & 0.3324 \\
\hline \multicolumn{6}{|c|}{ LXGIDA LBRENT LSUE LBIST-100 } \\
\hline $\mathrm{r}=0$ & 0.394592 & $95.22136^{\mathrm{a}}$ & 0.0000 & $56.70935^{\mathrm{a}}$ & 0.0000 \\
\hline $\mathrm{r}<1$ & 0.182231 & $38.51201^{\mathrm{b}}$ & 0.0211 & $22.73287^{\mathrm{b}}$ & 0.0435 \\
\hline $\mathrm{r}<2$ & 0.088144 & 15.77914 & 0.1850 & 10.42688 & 0.2970 \\
\hline $\mathrm{r}<3$ & 0.046261 & 5.352252 & 0.2470 & 5.352252 & 0.2470 \\
\hline \multicolumn{6}{|c|}{ LXTEKS LBRENT LSUE LBIST-100 } \\
\hline $\mathrm{r}=0$ & 0.438415 & $86.93806^{\mathrm{a}}$ & 0.0000 & $65.20004^{\mathrm{a}}$ & 0.0000 \\
\hline $\mathrm{r}<1$ & 0.099418 & 21.73802 & 0.3133 & 11.83275 & 0.5643 \\
\hline $\mathrm{r}<2$ & 0.071584 & 9.905274 & 0.2881 & 8.393124 & 0.3401 \\
\hline $\mathrm{r}<3$ & 0.013293 & 1.512149 & 0.2188 & 1.512149 & 0.2188 \\
\hline \multicolumn{6}{|c|}{ LXKAGT LBRENT LSUE LBIST-100 } \\
\hline $\mathrm{r}=0$ & 0.460451 & $92.16752^{\mathrm{a}}$ & 0.0000 & $71.57448^{\mathrm{a}}$ & 0.0000 \\
\hline $\mathrm{r}<1$ & 0.090206 & 20.59304 & 0.6889 & 10.96636 & 0.7530 \\
\hline $\mathrm{r}<2$ & 0.056723 & 9.626678 & 0.6764 & 6.773893 & 0.6970 \\
\hline $\mathrm{r}<3$ & 0.024293 & 2.852785 & 0.6086 & 2.852785 & 0.6086 \\
\hline
\end{tabular}

${ }^{\mathrm{a}} \mathrm{ve}^{\mathrm{b}}$ sirasıyla $\% 1$ ve $\% 5$ anlamlılık düzeyini göstermektedir.

Eşbütünleşme analizinden edinilen sonuçlar, doğal gaz ile petrolün özellikle önemli bir girdi olarak kullanıldığı bu sektörlere ilişkin endeks fiyatlarının hem doğal gaz hem de petrol fiyatları ile uzun dönemde aynı trende sahip olduğunu ortaya koymaktadır. Aralarında eşbütünleşme bulunan değişkenler arasındaki uzun dönem dengesi ve kısa dönem dinamikleri VECM ile analiz edilmiştir. Söz konusu analiz sonuçları Tablo 8 ve Tablo 9'da gösterilmektedir.

Tablo 8'den gözleneceği üzere hem hata terimi katsayıları hem de WALD testi sonuçları anlamsız bulunmuştur. Yani doğal gaz fiyatları ile ilgili endeksler arasında herhangi bir nedensellik ilişkisi tespit edilememiştir.

Tablo 8. VECM Sonuçları (Doğal gaz)

\begin{tabular}{|c|c|c|c|c|}
\hline & $\mathrm{p}$ & $\varepsilon_{t-1}$ & WALD Testi & Karar \\
\hline LDGAZ $\Rightarrow$ LXUSIN & 6 & 0.003 & 6.768 & Nedensellik yok \\
\hline LDGAZ $\Rightarrow$ LXTAST & 1 & 0.010 & 0.903 & Nedensellik yok \\
\hline LDGAZ $\Rightarrow$ LXMANA & 1 & 0.168 & 2.942 & Nedensellik yok \\
\hline LDGAZ $\Rightarrow$ LXKMYA & 1 & -0.002 & 1.136 & Nedensellik yok \\
\hline LDGAZ $\Rightarrow$ LXMESY & 6 & -0.009 & 11.543 & Nedensellik yok \\
\hline LDGAZ $\Rightarrow$ LXGIDA & 1 & -0.002 & 2.586 & Nedensellik yok \\
\hline LDGAZ $\Rightarrow$ LXTEKS & 1 & -0.009 & 3.471 & Nedensellik yok \\
\hline LDGAZ $\Rightarrow$ LXKAGT & 1 & $0.045^{\text {b }}$ & 2.702 & Nedensellik yok \\
\hline
\end{tabular}

Tablo 9'dan görüldüğü üzere petrol fiyatı ile XMESY, XGIDA ve XTEKS endeksleri arasında herhangi bir kısa dönemli ilişki tespit edilemezken, XUSIN, XTAST, XMANA, XKMYA ve XKAGT arasında petrol fiyatından ilgili endeks fiyatlarına doğru bir nedensellik ilişkisi olduğu bulunmuştur³.

Tablo 9. VECM Sonuçları (Brent)

\begin{tabular}{|c|c|c|c|c|}
\hline & $\mathrm{p}$ & $\varepsilon_{t-1}$ & WALD Testi & Karar \\
\hline LBRENT $\Rightarrow$ LXUSIN & 4 & 0.009 & $10.262^{\mathrm{c}}$ & LBRENT $\Rightarrow$ LXUSIN \\
\hline LBRENT $\Rightarrow$ LXTAST & 4 & -0.019 & $9.796^{\mathrm{c}}$ & LBRENT $\Rightarrow$ LXTAST \\
\hline LBRENT $\Rightarrow$ LXMANA & 1 & -0.001 & $4.813^{\mathrm{c}}$ & LBRENT $\Rightarrow$ LXMANA \\
\hline LBRENT $\Rightarrow$ LXKMYA & 4 & 0.001 & $11.990^{\mathrm{b}}$ & LBRENT $\Rightarrow$ LXKMYA \\
\hline LBRENT $\Rightarrow$ LXMESY & 4 & -0.006 & 7.243 & Nedensellik yok \\
\hline LBRENT $\Rightarrow$ LXGIDA & 4 & 0.006 & 8.306 & Nedensellik yok \\
\hline LBRENT $\Rightarrow$ LXTEKS & 4 & -0.005 & 4.855 & Nedensellik yok \\
\hline LBRENT $\Rightarrow$ LXKAGT & 1 & 0.001 & $4.849^{\mathrm{c}}$ & LBRENT $\Rightarrow$ LXKAGT \\
\hline
\end{tabular}

${ }^{\mathrm{b}} \mathrm{ve}^{\mathrm{c}}$ sirasıyla $\% 5$ ve $\% 10$ anlamll1ık düzeyini göstermektedir.

\section{SONUÇ}

Enerji, ülkelerin gelişmeleri açısından en önemli unsurların başında gelmektedir. Enerji kaynaklarının en önemlilerinden olan doğal gaz ve petrol ise, başta sanayi sektörü olmak üzere dünyada pek çok sektörde kullanılmaktadır. Bu açıdan doğal gaz ile petrol fiyatlarında meydana gelen dalgalanmalar, ülkelerin finansal piyasalarını ve hisse senedi fiyatlarını da etkileyebilmektedir.

Bu çalışmada, 2005:10-2015:09 dönemi için uluslararası doğal gaz fiyatları ve brent petrol fiyatları ile Borsa İstanbul'da işlem gören sanayi şirketlerinin oluşturduğu endeksler (Sınai, Taş-Toprak, Metal Ana, Kimya-Petrol-Plastik,

\footnotetext{
${ }^{3}$ VECM ile elde edilen kısa dönemli ilişkinin yönü VAR sistemine dayalı Granger (1969) nedensellik testi ile belirlenmiştir.
} 
Metal Eşya-Makina, Gıda-İçecek, Tekstil-Deri ve Orman-Kağıt-Basım) arasındaki ilişkinin test edilmesi amaçlanmıştır. Araştırmada ilgili değişkenlere ilişkin aylık TL bazlı fiyatlar kullanılmıştır. İlaveten çalışmada BIST-100 fiyat endeksi ile SUE kontrol değişkenleri olarak analizlere dahil edilmiştir. Öncelikle tüm değişkenlerin logaritmaları alınmış ardından serilere birim kök testleri uygulanmış ve birinci farklarının durağan olduğu tespit edilmiştir. Buradan aynı seviyede durağan oldukları tespit edilen serilerin uzun dönem ilişkilerinin test edilmesi amacıyla Johansen eşbütünleşme analizine geçilmiştir. Yapılan eşbütünleşme analizi sonucunda sanayi endeksleri ile ayrı ayrı olmak üzere doğal gaz ve petrol fiyatları arasında uzun dönemli ilişkinin var olduğu belirlenmiştir. Buna göre, doğal gaz veya petrol fiyatları ile uzun dönemde ilgili sektörlere ait endeks fiyatlarının aynı trende sahip olduğunu söylemek mümkündür. Bu durum petrol ve doğal gazın sanayi sektörü için önemli bir girdi olarak kullanılması nedeniyle beklenen bir sonuçtur.

Kısa dönemde ise, doğal gaz fiyatı ile endeks fiyatları arasında, herhangi bir nedensellik ilişkisi olmadığı görülmüştür. Ancak petrol fiyatı ile Sınai, Taş-Toprak, Metal Ana, Kimya-Petrol-Plastik ve Orman-Kağıt-Basım endeksleri arasında petrol fiyatından ilgili endekse doğru tek yönlü nedensellik olduğu tespit edilmiştir.

Tüm bu sonuçlar doğrultusunda, yatırımcıların bu sekiz endekste bulunan şirketlerin hisse senetlerine yatırım yaparken diğer makroekonomik faktörlerin yanında uzun dönemde hem doğal gaz hem de petrol fiyatındaki değişimleri, ayrıca kısa dönemde Sınai, Kimya-Petrol-Plastik, Metal Eşya-Makina, Metal Ana ve Gıda-İçecek endeksleri için, petrol fiyatındaki değişimleri dikkate alması önem arz etmektedir.

$\mathrm{Bu}$ sonuçlar doğal gazın veya petrolün alt endeksler üzerinde etkisi olduğunu ifade eden çalışmalar (Eryiğit 2009; Toraman ve diğ. 2011; Li ve Wen 2012; Güler ve Nalın 2013; Öztürk ve diğ. 2013; Abdioğlu ve Değirmenci 2014 ve Gönüllü ve diğ. 2015) ile örtüşmektedir. İlerleyen çalışmalarda ise farklı sektör endeksleri ile farklı enerji fiyatları arasındaki uzun ve kısa dönem ilişki incelenerek çalışma geliştirilebilir. 


\section{KAYNAKÇA}

Abdioğlu, Zehra ve Değirmenci Nurdan. 2014. "Petrol Fiyatları-Hisse Senedi Fiyatları İlişkisi: BIST Sektörel Analiz", Kafkas Üniversitesi İktisadi ve İdari Bilimler Fakültesi Dergisi, 5(8), 1-24.

Acaravcı, Songül Kakilli ve Reyhanoğlu, İzay. 2013. "Enerji Fiyatları ve Hisse Senedi Getirileri: Türkiye Ekonomisi İçin Bir Uygulama”, Nevşehir Hacı Bektaşi Veli Üniversitesi Sosyal Bilimler Enstitüsü Dergisi, 3(1), 94-110.

Acaravcı, Ali, Öztürk, İlhan ve Kandır, Yılmaz Serkan. 2012. "Natural Gas Prices and Stock Prices: Evidence from EU15 Countries", Economic Modelling, 29, 1646-1654.

Adaramola, Anthony Olugbenga. 2012, "Oil Price Shocks and Stock Market Behaviour: The Nigerian Experience", Journal of Economics, 3(1), 19-24.

Albayrak, Ali Sait, Öztürk Nurettin ve Tüylüoğlu, Şevket. 2012. "Makroekonomik Değişkenler ile Sermaye Hareketlerinin İMKB-100 Endeksi Üzerindeki Etkisinin İncelenmesi", Ekonomik ve Sosyal Araştırmalar Dergisi, $8(8), 1-22$.

Asteriou, Dimitrious., Dimitras, Augustinos ve Lendewig, Andrea. 2013. "The Influence of Oil Prices on Stock Market Returns: Empirical Evidence from Oil Exporting and Oil Importing Countries", International Journal of Business and Management, 8(18), 101-120.

Basher, Syed A. ve Sadorsky, Perry. 2006. "Oil Price Risk and Emerging Stock Markets". Global Finance Journal, 17, 224-251.

Beşergil, Bilsen. 2007. Hampetrolden Petrokimyasallara El Kitabı, http://www.bayar.edu.tr/besergil/hampetrolden_petrokimyasallara, 10.06.2015.

BIST 2015. Endeks Verileri, http://borsaistanbul.com/endeksler/endeks-verileri, Erişim tarihi: 10.01.2015

Bilgin, Recep, Sezgin, Fatih ve Altıner Bilal. 2013. "Uluslararası İlişkileri Şekillendiren Yeni Aktör Enerji: Kafkasya Örneği”, Nevşehir Hacı Bektaşi Veli Üniversitesi Sosyal Bilimler Enstitüsü Dergisi, 3(1), 52-65.

Boyer, Martin ve Filion, Didier. 2007, "Common And Fundamental Factors In Stock Returns Of Canadian Oil And Gas Companies", Energy Economics, 29(3), 428-453.

BP 2015 Statistical Review of World Energy June 2015, bp.com/statisticalreview, http://www.bp.com/content/dam/bp/pdf/energy-economics/statistical-review-2015/bp-statistical-review-of-worldenergy-2015-full-report.pdf, Erişim tarihi: 10.02.2015

Chen, Nai-Fu, Roll, Richard, Ross, Stephen. A. 1986. Economic Forces and the Stock Market. The Journal of Business, 59(3), 383-403.

Demirtaş, Özgür 2013. Türkiye'nin Enerji Görünümü, https://ekonomi.isbank.com.tr/UserFiles/pdf/ar_13_2013.pdf, Erişim tarihi: 11.02 .2015

Dickey, David A. ve Fuller, Wayne A. 1979. "Distribution of the Estimators for Autoregressive Time Series with a Unit Root", Journal of the American Statistical Association 74, 427-431.

Dickey, David A. ve Fuller, Wayne A. 1981. "Likelihood Ratio Statistics for Autoregressive Time Series with a Unit Root", Econometrica, 49, 1057-1072.

Enerji Piyasası Düzenleme Kurumu (EPDK). 2011. Doğal Gaz Piyasası 2011 Yılı Sektör Raporu, http://www.epdk.gov.tr/documents/dogalgaz/rapor_yayin/Dpd_Rapor_Yayin_Sektor_Raporu_2011_YML4K810np n7.pdf, Erişim tarihi: 11.02.2015

Enerji Piyasası Düzenleme Kurumu (EPDK). 2013. Doğal Gaz Piyasası 2013 Yılı Sektör Raporu, http://www.epdk.gov.tr/documents/dogalgaz/rapor_yayin/Dpd_Rapor_Yayin_Sektor_Raporu_2013.pdf.

EPDK 2015. Dünya ve Ülkemiz Enerji ve Tabii Kaynaklar Görünümü, http://www.enerji.gov.tr/File/?path=ROOT\%2f1\%2fDocuments\%2fEnerji+ve+Tabii+Kaynaklar+G\%C3\%B6r\%C3 \% BCn\%C3\%BCm\%C3\%BC\%2fSayi+08.pdf, Erişim tarihi: 11.02.2015

Eryiğit, Mehmet. 2009. "Effects of Oil Price Changes on the Sector Indices of Istanbul Stock Exchange", International Research Journal of Finance and Economics, 25, 209-216.

Eryiğit, Mehmet. 2012. "The Dynamical Relationship Between Oil Price Shocks And Selected Macroeconomic Variables in Turkey, Economic Research", Ekonomska istraživanja, 25(2), 263-276.

Faff, Robert ve Brailsford, Timothy J. 1999. "Oil Price Risk and The Australian Stock Market”, Journal of Energy Finance \& Development, 4(1), 69-87.

Gönüllü, Çağlar Ozan, Otluoğlu, Emir ve Şengöz, Mehmet Hakan. 2015. "Ham Petrol Fiyatı Değişimlerinin Petrokimya Sektörü Getirileri Üzerindeki Etkisi”, Uluslararast İktisadi İncelemeler Dergisi, 14, 223-234.

Granger, Clive William John. 1969. "Investigating Causal Relations by Econometric Models and CrossSpectral Methods", Econometrica, 37, 424-438.

Güler, Sevinç, Tunç, Ramazan ve Orçun, Çağatay. 2010. "Petrol Fiyat Riski ve Hisse Senedi Fiyatları Arasındaki İlişkinin Belirlenmesi: Türkiye'de Enerji Sektörü Üzerinde Bir Uygulama”, Atatürk Üniversitesi İktisadi ve İdari Bilimler Dergisi, 24(4), 297-315.

Güler, Sevinç ve Nalın, Halime Temel. 2013. "Petrol Fiyatlarının IMKB Endeksleri Üzerindeki Etkisi”. Ekonomik ve Sosyal Araştırmalar Dergisi, 9(2), 79-97.

Güney Ege Kalkınma Ajans1 (GEKA) 2012. Enerji Sektörü Raporu, http://geka.org.tr/yukleme/planlama/Sekt\%C3\%B6rel\%20Ara\%C5\%9Ft\%C4\%B1rmalar/Enerji\%20Sekt\%C3\%B6r \%C3\%BC\%20Raporu.pdf, Erişim tarihi: 14.02.2015 
Eyüboğlu, K., Eyüboğlu, S. / Journal of Yasar University, 2016, 11/42, 150-162

http://www.bloomberght.com/haberler/haber/1504087-turkiyenin-enerji-ithalat-faturasi-55-9-milyar-dolar, Erişim tarihi: 11.03.2015

Huang, Roger D. Masulis, Ronald. W. \& Stoll, Hans R. 1996. “Energy Shocks and Financial Markets,” Journal of Futures Markets, 16(1), 1-27.

Johansen, Sorensen. 1988. "Statistical Analysis of Cointegration Vectors," Journal of Economic Dynamic and Control, $12,231-254$.

Johansen, Soren ve Juselius, Katarina. (1990). "Maximum Likelihood Estimation and Inferences on Co-Integration with Applications to the Demand for Money", Oxford Bulletin of Economics and Statistics, 52, 169-210.

Investing. com, http://www.investing.com/commodities/natural-gas-historical-data, Erişim tarihi: 05.05.2015

İşcan, Erhan. 2010. "Petrol Fiyatının Hisse Senedi Piyasası Üzerindeki Etkisi”, Maliye Dergisi, 158, 607-617.

Jones, Charles M. ve Kaul, Gautam. 1996. "Oil and the Stock Markets”, The Journal of Finance, 51(2), 463-491.

Kamuyu Aydınlatma Platformu (KAP). http://www.kap.gov.tr/sirketler/islem-goren-sirketler/endeksler.aspx, Erişim tarihi: 18.01 .2016

Kapusuzoğlu, Ayhan. 2011. "Relationships between Oil Price and Stock Market: An Empirical Analysis from Istanbul Stock Exchange (ISE)", International Journal of Economics and Finance, 3(6), 99-106.

Le, Thai-Ha. ve Chang, Youngho. 2011. "The Impact of Oil Price Fluctuations on Stock Markets in Developed and Emerging Economies”. Singapore Economic Review Conference.

Li, Hua ve Wen, Zhu. 2012. "Causal Relation Between Macro Economy and Industrial Index Based on Regression Analysis", Journal of Theoretical and Applied Information Technology, 46(2), 754-761.

Malik, Farooq ve Ewing, Bradley T. 2009. "Volatility Transmission Between Oil Prices and Equity Sector Returns", International Review of Financial Analysis, 18, 95-100.

Masih, Rumi, Sanjay, Peters ve Mello, Lurion De. 2011. "Oil Price Volatility and Stock Price Fluctuations in an Emerging Market: Evidence from South Korea”, Energy Economics, 33, 975-986.

Nandha, Mohan ve Hammoudeh, Shawkat. 2007. "Systematic Risk, and Oil Price and Exchange Rate Sensitivities in Asia-Pasific Stock Markets”, Research in International Business and Finance, 21(2), 326-341.

Narayan Paresh Kumar ve Narayan Seema. 2010. “Modeling the Impact of Oil Prices on Vietnam's Stock Prices”, Applied Energy, 87, 356-361.

Özmerdivanlı, Arzu. 2014. "Petrol Fiyatları ile BIST 100 Endeksi Kapanış Fiyatları Arasındaki İlişki”, Akademik Bakış, $43,1-12$.

Öztürk, M.B., Gümüş, G.K., Taşkın, F.D. ve Çağl1, E.Ç. 2013. "Petrol ve Doğalgaz Fiyatları ile İmalat ve Kimya-PetrolPlastik Sektörlerinin Endeksleri Arasındaki İlişki”, Niğde Üniversitesi İ̈BF Dergisi, 6(2), 64-74.

Papapetrou, Evangelia. 2001. "Oil Price Shocks, Stock Market, Economic Activity and Employment in Greece”, Energy Economics, 23(5), 511-532.

Park, Jungwook ve Ratti, Ronald A. 2008. "Oil Price Shocks and Stock Markets in the U.S. and 13 European Countries", Energy Economics, 30(5), 2587-2608.

Phillips, C.B. Peter ve Pierre, Perron. 1988. "Testing For a Unit Root in Time Series Regression”, Biomètrika 75(2), 336346.

Sadorsky, Perry. 1999. “Oil Price Shocks and Stock Market Activity”, Energy Economics, 449-469.

Sarı, Ramazan. ve Soytaş, Uğur. 2006. "The Relationship between Stock Returns, Crude Oil Prices, Interest Rates and Output: Evidence from a Developing Economy", The Empirical Economics Letters, 5(4), 205-220.

Sayılgan, Güven ve Süslü Cemil. 2011. "Makroekonomik Faktörlerin Hisse Senedi Getirilerine Etkisi: Türkiye ve Gelişmekte Olan Piyasalar Üzerine Bir İnceleme”, BDDK Dergisi, 5(1), 73-96.

Sohtaoğlu, Nazif Hülagü ve Erbaş Fatih. 2006. "Enerji Kaynaklarının Arz ve Talebine Yönelik Küresel Eğilimlerin Tarihsel Süreçte Karşılaştırmalı Analizi”. Dünya Enerji Konseyi Türk Milli Komitesi Türkiye 10. Enerji Kongresi, http://www.dektmk.org.tr/pdf/enerji_kongresi_10/Nazif_Hulagu.pdf, Erişim tarihi: 19.03.2015TMMOB Makine Mühendisleri Odası. 2008. Dünyada ve Türkiye'de Enerji Verimliliği Oda Raporu, http://www.mmo.org.tr/resimler/dosya_ekler/a551829d50f1400_ek.pdf.

Türkiye Cumhuriyet Merkez Bankası (TCMB). http://evds.tcmb.gov.tr/ Erişim tarihi: 18.01.2016.
TMMOB
Makine
Mühendisleri
Odas1
(2015).
Türkiye
Enerji Görünümü, http://www.mmo.org.tr/yayinlar/kitap_goster.php?kodu=379, Erişim tarihi: 11.05.2015

Toraman, Cengiz Başarır Çağatay ve Bayramoğlu, Fatih M. 2011. "Effects of Crude Oil Price Changes on Sector Indices of Istanbul Stock Exchange”. European Journal of Economic and Political Studies 2, 109-124.

Türkiye Petrolleri Anonim Ortaklığı (TPAO). 2014. Ham Petrol ve Doğalgaz Sektör Raporu, Mayıs 2014.

Ünlü, Ulaş ve Topçu, Mert. 2012. "Do Oil Prices Directly Affect Stock Markets: Evidence from Istanbul Stock Exchange", Iktisat, İşletme ve Finans, 27(319), 75-88.

Yıldırım, Murat, Bayar, Yılmaz ve Kaya Abdülkadir. 2014. "Enerji Fiyatlarının Sanayi Sektörü Hisse Senedi Fiyatları Üzerindeki Etkisi: Borsa İstanbul Sanayi Sektörü Şirketleri”, Muhasebe ve Finansman Dergisi, 93-108. 